\title{
Novice and Experienced EFL Teachers: Which Professional Development Programs Matters for Our Classroom?
}

\author{
Shandra Nitalinawati \\ Pendidikan Bahasa Inggris-Universitas Negeri Malang
}

\section{INFO ARTIKEL}

\section{Riwayat Artikel:}

Diterima: 02-01-2020

Disetujui: 16-09-2020

Kata kunci:
novice and experienced teachers'
perceptions;
professional development;
impact;
persepsi guru pemula dan
berpengalaman;
pengembangan profesional;
dampak

\section{Alamat Korespondensi:}

Shandra Nitalinawati

Pendidikan Bahasa Inggris

Universitas Negeri Malang

Jalan Semarang 5 Malang

E-mail: shanalifikri87@gmail.com

\begin{abstract}
ABSTRAK
Abstract: This study aimed at exploring the perceptions of EFL novice and experienced teachers on the impact of professional development programs to their teaching practice. The design of this study is a descriptive study by using in-depth interviews for gaining the data. The result of this study revealed that novice and experienced teachers have different needs in developing their professionalism. This differences then lead to different preferences of development programs which really fulfill their needs and influence their teaching practice. Meanwhile, both teachers agree that the time permission is the most important factor of a successful development programs for teachers.
\end{abstract}

\begin{abstract}
Abstrak: Penelitian ini menyelidiki persepsi guru Bahasa Inggris pemula dan guru berpengalaman dalam dampak kegiatan pengembangan keprofesian terhadap kegiatan pembelajaran mereka. Metode yang digunakan dalam penelitian ini adalah metode wawancara mendalam dengan pertanyaan-pertanyaan terbuka. Hasil dari penelitian ini menunjukkan bahwa guru bahasa Inggris pemula dan berpengalaman memiliki kebutuhan yang berbeda dalam mengembangkan profesionalisme mereka. Perbedaan ini kemudian mengarah pada perbedaan pilihan kegiatan pengembangan keprofesian
\end{abstract}

One of the ways for teachers in order to always maintain and pursue their competence is by engaging in professional development. Teacher professional development is teachers' lifelong effort and engagement in pursuing the improvement of the teaching practice quality through advancing knowledge and proficiency with formal and informal activity. In other words, as stated by Harwell (2003), professional development is sustained engagement. It is not a one-shot program but a continuous process aimed at promoting teachers' knowledge, proficiency, and characters (Katuuk \& Marentek, 2014). Therefore, in line with Richards and Farrels (2005), professional development obliges a longer-term aim and enables the growth of teachers' professional and personal improvement.

Some literatures have already proven that actively involved in professional development activity will ensure teachers in sustainably retaining good competences and performance and renewing their knowledge as well as their skills based on the new trends and challenges in educational field (Borko, 2004; Richards \&Farell, 2005; Yates, 2007; Archibald, Coggshall, Croft, \& Goe, 2011; Hismanoglu \& Hismanoglu, 2010; Katuuk \& Marentek, 2014; Ravhuhali, Kutame \& Mutshaeni, 2015, Mahmoudi \& Ozkan, 2015; Mohan, 2016, Golob, 2012 and many others). As a result, there are numerous types of professional development are now offered to teachers. OECD TALIS (2009) recognizes 18 types of formal form of professional development (including courses/workshops, conferences or seminars, qualification programme, observation visits to other schools, participation in a network of teachers formed specifically for the professional development of teachers, individual or collaborative research on a topic of professional interest, and mentoring and/or peer observation and coaching) and less formal ones (reading professional literature and engaging in informal dialogue with peers).

On the other hand, a study by Hustler, McNamara, Jarvis, Londra \& Campbell (2003) mentioned a more specific type of professional development required for teachers in the United Kingdom such as INSET (In-Service Education for Teachers). This kind of program is actually also conducted in Indonesia, although it is not yet widely applied. This program is seen as an effective one, as teachers are able to develop not only their professional competence but also pedagogical and social competence (Cahyono, 2017). Furthermore, still in the same study, Hustler et al (2003) also identify less formal activities, for example, peer coaching and personal reading.

Meanwhile, Desimone, Porter, Garet, Yoon \& Birman (2002)'s longitudinal study distinguished the professional development activity engaged by teachers into two groups: traditional type (within-district workshops or conferences, courses for college credit, and out-of- district workshops or conferences) and reform type (teacher study groups, teacher collaboratives, 
networks, or committees, mentoring, internships, and resource centers). In addition, Kusumawardhani \& Widiati (2013) also conducted a study examining the type of professional development for teachers. The findings of their study further exposed that in order to gain and update the competences, the teachers in Tulung Agung joined seminars, workshops, and training and forming a teacher forum called MGMP (Musyawarah Guru Mata Pelajaran) where they can share and discuss with the fellow teachers. Moreover, they also create some innovations regarding the innovation of effective and efficient technology, artworks, and learning tools, as well as composing standards, manuals, constructing test items. Furthermore, the certified teachers also engaged in less formal activities which do not relate to their professional and pedagogical competence but relate more on gaining their social competence, such as having a dialogue with colleagues and also being active in the social community by joining activities such as arisan, PKK, etc.

Despite the various types of development programs are offered and provided for teachers, an issue of how well the training answered the teachers' needs, and how effective those training to the teachers in doing their day to day activities was raised towards professional development programs for teachers (Setiawan, 2009). Darling-Hammond, Wei, Andree, Richardson, \& Orphanos (2009) even claimed that despite engaging in various kinds of activity to develop their professionalism, most teachers reported that they obtained no beneficial change in their competence and mentioned that it was completely impractical. Similarly, Gulamhussein (2013) explained that today's concern about teacher professional development is not about the availability but the quality of the activity.

In addition, Desimone (2009) argued that an active professional development initiative should include several qualities: it should be based on the teacher's and school's needs, integrated with mentoring, and enclosed teaching practices into the daily work of teachers. On the other hand, studies by Mahmoudi and Ozkan, 2015 and Mohan (2016) recognized the different needs and preference for professional development activity between novice and experienced teachers. However, most of the professional development activities available today are designed generally for all teachers without considering the different needs between novice and experience teachers. Furthermore, most of today's development programs are top-down activities, designed by experts or certain institutional without involving teachers. Teachers are just obliged to join a particular program without even being asked whether or not the program will be useful for the teachers. On the other words, teachers are forced to engage with professional development which does not fit the actual needs to improve their teaching practice (Evans, Tate, Navarro, \& Nicolls, 2009). Utami \& Prestridge (2018) argued that profesional development programs should be base don what teachers need to ignite them apply the new knowledge to the classrooms.

Hence, an investigation on how novice and experienced teachers perceive the impact of their professional development programs is worth doing in order to explore the differences and the similarities of their efforts in pursuing their professionalism. Novice and experienced teachers are considered different in terms of knowledge, skills, and beliefs which lead to different need of professional development (Rodriguez \& McKay, 2010). With only a short length of teaching experience, novice teachers need the ability to adjust their knowledge and ability with their classrooms (Akcan, 2015; Kong, 2016). Clark (2012) and Boakye \& Ampiah (2017) implied that novice teachers faced a new confronting environment which they find difficult to deal with unless they get supports from the surroundings. Furthermore, novice teachers need guidance to improve their teaching competence (Akcan, 2015). Meanwhile, experienced teachers need to maintain the knowledge and experience they pursued so far (Rodriguez \& McKay, 2010).

Therefore, this research will focus on studying the perception of novice and experienced EFL teachers on the impact of professional development. The result of this study is expected to provide teachers and also school principals with information about what kind of professional development activity which is really can be beneficial for the teachers' development. In addition, the findings of this study will also give a contribution to the authorized institutions that provide professional development programs.

\section{METHODS}

This study was aimed to investigate EFL novice and experienced teachers' perceptions of the impact of professional development programs. Therefore, it attempted to explore the teachers' insights and experiences in pursuing their professionalism through development programs. The instrument used in this study to collect the data semi-structured was indepth interview with open-ended questions. The interviews were done separately between the two teachers. Both teachers were interviewed three times for each subject in order to gain reliable information from the subjects.

The subjects of this study were one novice English teacher and one experienced English teacher. The selection of the subject was based on four criteria (1) currently teaching English in a reputable junior or senior or vocational high school; (2) having less than 3 years or exactly 3 years in teaching English of secondary school for the novice teacher, and exactly or more than 10 years in teaching English in secondary school; (3) actively participating in more than one types of professional development program; (4) considered as one of the outstanding teachers in the school based on the environment; (5) graduated from a reputable university. The novice teacher in this study is a junior high school teacher who has been teaching for less than three years and has actively engaged in pursuing the professionalism through the development programs. Meanwhile, the experienced teacher in this study has been teaching for more than ten years and is currently teaching in one of senior high schools in Malang. She also actively engaged with development programs in order to maintain and improve the quality of her teaching. Both teachers are considered as the excellent teachers by their fellow colleagues. 
An interview guide was constructed based on six themes (1) the opinion about the subjects' experiences in teacher professional development; (2) the need of teacher professional development; (3) types of professional development engaged for improving pedagogic and professional competence; (4) the impact of each type of professional development programs on the teaching practice; (5) The factors influencing the impact of professional development programs; (6) The most beneficial professional development program(s) for the process in improving the teaching practice. The first and the second themes were would reveal that all teachers (senior, long-serviced, and early aged teachers) have the same view about the responsibility in improving their competence. The third theme was meant to reveal the novice and experienced teachers' preference for professional development programs to improve their professional and pedagogic competence. Furthermore, the fourth theme was intended to investigate the impact of each type of professional development program preferred by the subjects. The indicators of the impact are based on the findings of Powel et al. (2003) and Ravhuhali et al. (2015)'s research findings. On the other hand, the fifth and sixth theme concluded the types of professional development programs which affected the teaching practice at most and elaborated the factors which make the programs successful. This interview guide was validated by an expert to ensure the reliability of the questions

The data analysis in this study started with transcribing the conducted interviews. The audio-recorded data was transcribed into a transcript. After transcribing the data, the next step was coding. The transcribed data was then coded based on the categories related to the research questions. After grouping the subjects' utterances based on the theme of the research, an interpretation was made. After that, the issues that emerged were analyzed based on the pertinent theories and previous studies.

\section{RESULTS}

\section{Teachers' Perceptions about Professional Development}

In this study, when being asked about the experience of professional development, Novice Teacher (NT) emphasizes that her joining in professional development programs is mainly to improve her ability in preparing her teaching activity in the classroom. This preparation includes composing the lesson plan, selecting the material and media suitable for her class, and creating the right assessment for her students. Similar to the Novice Teacher (NT), Experienced Teacher (ET) states that she has been engaging with professional development programs as her effort in elevating and updating her teaching competence since the first year of teaching. However, unlike NT, ET emphasizes that she needs development programs to maintain and improve the quality of her teaching practice. She contends that she can have new ideas in how she will deliver the lesson better, and also enrich her own knowledge as an educator through the development programs.

\section{Teacher Professional Development Programs}

Consistent with her statement about her experience with professional development programs so far, Novice Teacher (NT) reports that she has attended some seminars and workshops to improve her competence. She specifically mentions that most of the workshops and seminars' materials were related to how to make a better lesson plan. Furthermore, NT states that the majority of these seminars and workshops were the obligatory programs of her school. Beside that, she also mentions that she joins some other types of activities such as MGMP (Musyawarah Guru Mata Pelajaran) and Lesson Study which both again emphasize making and revising the lesson plan. In addition, NT stated that she also often has dialogues with her senior colleagues to discuss about her classrooms. In fact, she stated that she actually needed a guidance or mentoring form her senior colleagues. She felt that it would help her improving her confidence and teaching practice. However, there is no mentoring program for new teachers available at her school.

Experienced Teacher (ET) reveals that she joins more various types of professional development programs and activities. With her more than ten years of teaching experience, ET seems to have more thoughtful choices to develop her competence. Unlike NT whose programs are mainly seminars and workshops, most of the programs and activities she joining are the autonomous types for example, conducting research and reading related literature.

\section{The Impact of Professional Development Programs to the Teaching Practice}

NT exposes that she received much knowledge from all of the programs she has joined, both pedagogic and professional knowlegde. She reports that the development activity she joined before as seminars provided her with new professional knowledge about the subject matter and pedagogical knowledge as well such as teaching strategy and techniques. For the workshops, at first, she says that it gave her professional knowledge about how to make a better lesson plan and module. When the researcher confirms why making a lesson plan and module belong to professional knowledge, she elaborates that it makes her prepare her lesson plan more professionally. As a result, NT argues that workshops and seminars are the two most beneficial programs she has joined so far. The reason is, as she explained, related to a certain topic regarded as the most crucial one for her, lesson plan. As mentioned before, NT explains that most of the seminars and workshop topics she joined were about lesson planning.

Similar to NT, ET also reports that she attains much impact from the development programs and activities she has joined or is currently joining. Nevertheless, the impact she receives is slightly different from the NT did. ET has a more advanced impact than NT did. Previously, NT emphasizes that the professional development activities she joins help her in adjusting her teaching with the real classroom situation. Meanwhile, ET elaborates that she gets more than just adjusting to the 
classroom situation. She integrates all the new knowledge she acquires, sorts it for the improvement of her classroom and then decides to make changes. However, she then explains how the knowledge from each activity or program sparks the initiative to have better teaching practice. Therefore, different from NT, ET is first uncertain when the researcher asked her to mention the best development program or activity based on her own opinion. She feels that the impact she gets in her classroom is actually the effect of all the knowledge she gets from the different types of professional development programs and activities. However, ET then mentions that the best program for her is the master program she has just finished a while ago. She contends that through this program she does not only acquire pedagogic and professional knowledge but also updates her teaching skills through teaching practicum and sharing valuable experience with other teachers from a different region.

\section{The Factors of Successful Professional Development Programs}

As a novice teacher, NT argues that the content or the topic of the development programs should be simple, easy to understand and effectively applicable in the real classroom situation. Furthermore, NT mentions that in order to successfully enhancing teachers' competence, professional development programs should include a follow-up activity. She further explains that the follow-up activity should be supervised because as a new teacher she feels that she still needed feedback in changing her classroom practice. In short, topics and follow-ups are the two most important factors suggested by NT for a successful development programs.

Meanwhile, ET argues that the most important factor of development programs is the time. As she mentioned before, she currently almost cannot attend any workshops or seminars or any development programs which require her to leave at the school hours. Therefore, she further explains that a professional development program should guarantee the participant to be able to attain and apply new knowledge. In other words, she emphasizes that a successful development program should include permission so that teachers can have a specific time for the development programs.

\section{DISCUSSIONS}

Mohan's (2016) study showed that novice and experienced teachers had differences pertinent to professional development preferences. This study confirms the findings. The study reveals that novice teachers tend to select professional development programs that relate to teaching strategy, classroom management, and school culture, the same as NT's preferences which she finds useful for her teaching preparation. Moreover, NT also argued that she needed support from the school, especially form the fellow senior teachers in order to gain confidence and improve her teaching pactice. This is in line with Qayen, Abadi \& Naimi (2013) who suggested that novice teachers need supports, one of them in the form of coaching guide. Warsame \& Valles (2012), and Hudson (2012) also mention that mentoring and supportive environments are paramount for novice teachers. Furthermore, NT stated that she also gained much knowledge from the informal dialogue with her senior colleagues. Jin, Li, Meirink, Want, \& Admiraal (2019) argued that the interaction between novice and experienced teachers plays a significant role to the improvement of both teachers, especially novice teachers. It strengthens Ingersoll \& Strong (2011) and Valickis (2014)'s conclusions that mentoring for novice teachers is essential in helping them attain better teaching competence.

Meanwhile, similar to Mohan's (2016) findings, this study also reveals that experienced teachers tend to prefer activities which provide the knowledge on school policy and reforms, neighborhood organization and the use of latest technology in students' learning and teaching.which can refine and improve not only the quality of their teaching and learning process but also her understanding, awareness, and professionalism. Besides, as ET also prefer to have a collaborative development programs which enable her to broaden her knowledge and skills (Rodriguez \& McKay, 2010). However, despite the differences in the purpose and selection of professional development programs, this study also shows that both novice and experienced teachers admitted the importance of engaging with development programs as the stairs towards better competence.

On the other hand, NT and ET had some different types of professional development programs during their teaching years. NT was mostly engaged with school seminars and workshops about composing a better lesson plan. Meanwhile, ET chose the autonomous programs which did not take place in the school time due to the limited permission from the principal. It confirms Mohan's (2016) findings of novice and experienced teachers' difference needs of development programs. This needs then influence their purpose and the selections of the programs which also lead to different achievements.

Similar to previous research findings mentioned before (Archibald, et. Al, 2011; Hismanoglu \& Hismanoglu, 2010; Katuuk \& Marentek, 2014; Ravhuhali, Kutame \& Mutshaeni, 2015, Mahmoudi \& Ozkan, 2015; Mohan, 2016, and many others), both NT and ET agreed that the development programs they joined have given a huge impact on their development of teaching competence. NT clearly explained that the ultimate impact she got from all the programs was the change in her lesson plan. She stated that the knowledge she attained made her change the lesson plan and also her teaching practice in the class. On the other words, she did improve her pedagogical and professional competence through the better teaching skill, matching the media, the strategy and the materials with the students, and personal competence, as well as she, stated that after joining the programs she felt more confident and connected with her students in the class. She adapted her prior knowledge and skills from college with her classrooms situation through the school-based development programs. This is in line with Akcan (2016) and Kong (2016) whose findings reveal that novice teachers need the capability to adjust themselves with the requirements of their schools. By contrast, ET uttered that she could not easily mention one of the programs as the most beneficial one since she 
contended that the impact she got was actually from the integrated knowlegde from all of the programs. In other words, unlike NT who directly makes use of the knowledge she got from one program, ET combined what she got to improve her teaching practice. As stated by Rodriguez \& McKay (2010), experienced teachers need the chance to engage with self-directed, collective, thoughtful programs which challenge them to broaden their knowledge and skills. Therefore, unlike NT who mentioned workshops and seminars as the most beneficial programs for her, ET argued that the master program she has joined has given her the most benefit to the betterment to her teaching practice. She elaborated that it was because she could engage with various development activity during her master program.

Despite the different purposes and needs, both novice and experienced teachers agree that time permission is the main factor of a successful development program. They similarly elaborate that a program which includes the time permission to apply the knowledge affects the improvement in the teaching practice the most. Both teachers assure that they will gain more impact in their teaching practice when they get more time to engage with development programs and then apply the knowledge into their classrooms. In addition, suitable topics and follow-ups are also considered as important for the success of teacher development programs.

\section{CONCLUSIONS}

Based on the research findings and discussions, it is concluded that novice and experienced teachers have different purposes in engaging with the professional development programs in improving their teaching practice. This difference also leads to different preferences for professional development programs. As a beginner, the novice teacher mainly needs to adapt the background knowledge she attained from college with the real classroom situation. Furthermore, she needs a mentor in helping her adjusting to the school. On the other hand, the experienced teacher has already been in the real classroom situation for a while so that instead of adapting, she needs to modify to create some new strategy to improve her teaching. Therefore, the experienced teacher is convinced that all types of professional development contribute to her improvement. Meanwhile, despite the different purposes and needs, both novice and experienced teachers agree that time permission is the main factor of a successful development program. They similarly elaborate that a program which includes the time permission to apply the knowledge affects the improvement in the teaching practice the most.

The current study was involved a small number of participants, therefore, it is suggested that the next research should be conducted involving more number of participants for more representative results. Furthermore, it is also advocated to investigate the impact of development programs on the classroom practice by having observational research.

\section{REFERENCES}

Akcan, S. (2016). Novice Non-Native English Teachers' Reflections on Their Teacher Education Programmes and Their First Years of Teaching. PROFILE Issues in Teachers' Professional Development, 18(1), 55-70. https://doi.org/10.15446/profile.v18n1.48608

Archibald, S., Coggshall, J. G., Croft, A., \& Goe, L. (2011). High-Quality Professional Development for All Teachers: Effectively Allocating Resources. National Comprehensive Center for Teacher Quality, 32.

Badri, M., Alnuaimi, A., Mohaidat, J., Yang, G., \& Al Rashedi, A. (2016). Perception of Teachers' Professional Development Needs, Impacts, and Barriers: The Abu Dhabi Case. SAGE Open, 6(3). https://doi.org/10.1177/2158244016662901

Boakye, C., \& Ampiah, J. G. (2017). Challenges and Solutions: The Experiences of Newly Qualified Science Teachers. SAGE Open, 7(2). https://doi.org/10.1177/2158244017706710

Borko, H. (2004). Professional Development and Teacher Learning: Mapping the Terrain. Educational Researcher, 33(8), 3-15. https://doi.org/10.3102/0013189X033008003

Cahyono, B.Y. (2017). Indonesian EFL Secondary School Teachers' Perceptions on How In-service Education Teaching Practices Improved Their Competences. Paper was presented at the National English Language Teacher of Secondary Education (NELTISE) Conference at Graduate Program of Universitas Negeri Malang, Malang, February, $4^{\text {th }}, 2017$.

Darling-hammond, L., \& Wei, R. C. (n.d.). (2009). Professional Learning in the Learning Profession: A Status Report on Teacher Development in the U.S. and Abroad. Technical Report. National Staff Development Council.

Desimone, L.M., Porter, A. C., Garet, M.S., Yoon, K.S., Birman, B. F. (2002). Effects of Professional Development on Teachers' Instruction: Results from a Three-Year Longitudinal Study. Educational Evaluation and Policy Analysis Summer, 24(2), 81-112.

Evans, D., Flora, C., Goodpastor, G., Shepherd, P., \& Tolo, K. (2009). Assessment of Indonesia Higher Education Institutional Capacity in Selected Geographic and Subject Areas. Produced for the USAID/Indonesia under a Task Order 25 of the Global Evaluation and Monitoring.

Golob, H. M. (2012). The Impact of Teacher's Professional Development on the Results of Pupils at National Assessment of Knowledge. Procedia - Social and Behavioral Sciences, 47(2005), 1648-1654. https://doi.org/10.1016/j.sbspro.2012.06.878

Gulamhusein, A. 2013. Teaching the Teachers: Effective Professional Development in an Era of High Stakes Accountability. The Center for Public Education. 
Hismanoglu, M., \& Hismanoglu, S. (2010). English Language Teachers' Perceptions of Educational Supervision in Relation to Their Professional Development: A Case Study of Northern Cyprus. Novitas-ROYAL (Research on Youth and Language), 4 (1), 16-34.

Hudson, P. (2012). How can schools support beginning teachers? A call for timely induction and mentoring for effective teaching. Australian Journal of Teacher Education, 37(7), 71-84. https://doi.org/10.14221/ajte.2012v37n7.1

Hustler, D., Mcnamara, O., Jarvis, J., Londra, M., \& Campbell, A. (2003). Teachers' Perceptions of Continuing Professional Development. Department for Education and Skills, 1-278.

Katuuk, D., \& Marentek, M. K. L. (2014). Indonesian Primary School Teacher's Perception of Professional Development Programs: A Case Study. International Journal of Education and Research, 2(6), 629-634.

Kong, Y. (2016). Problems and Solutions to Professional Development of Novice College English Teachers: A Case Study on Chinese Local HEIs. 12(10), 56-61. https://doi.org/10.3968/8852

OECD. 2009. Creating Effective Teaching and Learning Environments: First Results from TALIS.

Ingersoll, R. M., \& Strong, M. (2011). The Impact of Induction and Mentoring Programs for Beginning Teachers: A Critical Review of the Research. In Review of Educational Research (Vol. 81). https://doi.org/10.3102/0034654311403323

Jin, X., Li, T., Meirink, J., van der Want, A., \& Admiraal, W. (2019). Learning from Novice-Expert Interaction in Teachers' Continuing Professional Development. Professional Development in Education, 00(00), 1-18. https://doi.org/10.1080/19415257.2019.1651752

Kusumawardhani, A. P., \& Widayati, S. (2013). The Professional Development of Certified English English Teachers at SMPN 1 Tulungagung. Unpublished Thesis. Universitas Negeri Malang.

Mahmoudi, F., \& Özkan, Y. (2015). Exploring Experienced and Novice Teachers' Perceptions about Professional Development Activities. Procedia - Social and Behavioral Sciences, 199, 57-64. https://doi.org/10.1016/j.sbspro.2015.07.487

Mohan, P.P. (2016). A Study on Novice and Experienced Teacher Perceptions of Professional Development in Fiji. In N. Wright (Eds), Waikato Journal of Education, 21(1), 167-174.

Powell, E. et.al. (2003). Teachers' Perceptions of the Impact of CPD: An Institutional Case Study. Journal of In-Service Education, 29(3). www.tandfonline.com/doi/abs/10.1080/13674580300200225

Qayen, N. Y. N., Reza, H., Abadi, H.R.Z., \& Naimi, S. (2013). Which Needs Should be Emphasized to Help Novice Teachers? The Findings of a Qualitative- Quantitative Study in Primary Schools of Tehran, 2(3), 2126-2137.

Ravhuhali, F., Kutame, A. P., \& Mutshaeni, H. N. (2015). Teachers' Perceptions of the Impact of Continuing Professional Development on Promoting Quality Teaching and Learning. International Journal of Educational Sciences, 10(1), 1-7. https://doi.org/10.1080/09751122.2015.11890332

Richards, J.C. and Farrell, T.S.C. (2005). Development for Language Teachers: Strategies for Teacher Learning. Cambridge: Cambridge University Press.

Rodríguez, A., \& McKay, S. (2010). Professional Development for Experienced Teachers Working with Adult English Language Learners. CAELA Network Brief. CAELA Network Brief, (May). Retrieved from http://eric.ed.gov/?id=ED540598

Clark, S. K. (2012). The Plight of the Novice Teacher. The Clearing House: A Journal of Educational Strategies, Issues and Ideas, 85(5), 197-200. https://doi.org/10.1080/00098655.2012.689783

Setiawan, R. (2009). The Effectiveness of Teacher Training in Indonesia: A Practice by Sampoerna Foundation Teacher Institute (SFTI). German Institute for Adult Education

Utami, I. G. A. L. P., \& Prestridge, S. (2018). How English Teachers Learn in Indonesia: Tension between Policy-Driven and Self-Driven Professional Development. Teflin Journal, 29(2), 245-265. https://doi.org/10.15639/teflinjournal.v29i2/245265

Poom-Valickis, K. (2014). Novice Teachers' Professional Development During the Induction Year. Procedia - Social and Behavioral Sciences, 112(Iceepsy 2013), 764-774. https://doi.org/10.1016/j.sbspro.2014.01.1228

Warsame, K., \& Valles, J. (2018). An Analysis of Effective Support Structures for Novice Teachers. Journal of Teacher Education and Educators, 7(1), 17-42.

Yates, S. M. (2007). Teachers' Perceptions of Their Professional Learning Activities. International Education Journal, 8(2), 213-221. 